\title{
Hamartoma: a rare developmental disorder
}

\author{
BARTŁOMIEJ J. BARTYZEL, ANDRZEJ MAX*, JOANNA GRUSZCZYŃSKA**, \\ MAŁGORZATA SOBCZAK-FILIPIAK***, TOMASZ MĘCIK-KRONENBERG****, \\ FILIP PANKOWSKI
}

\author{
Department of Morphological Sciences, Faculty of Veterinary Medicine, \\ Warsaw University of Life Sciences, Nowoursynowska 159, 02-776 Warszawa, Poland \\ *Department of Small Animal Diseases with Clinic, Faculty of Veterinary Medicine, \\ Warsaw University of Life Sciences, Nowoursynowska 159c, 02-776 Warszawa, Poland \\ **Department of Genetics and Animal Breeding, Faculty of Animal Science, \\ Warsaw University of Life Sciences, Ciszewskiego 8, 02-786 Warszawa, Poland \\ ***Department of Pathology and Veterinary Diagnostics, Faculty of Veterinary Medicine, \\ Warsaw University of Life Sciences, Nowoursynowska 159c, 02-776 Warszawa, Poland

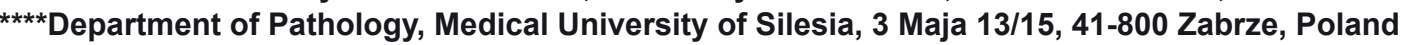

\section{Bartyzel B. J., Max A., Gruszczyńska J., Sobczak-Filipiak M., Męcik-Kronenberg T., Pankowski F. Hamartoma: a rare developmental disorder}

Summary

Hamartoma is a developmental disorder of various body parts and organs. It is characterized by a nonneoplastic growth of tissue with an uneven distribution and proportion of individual cells. Lesions progress for several years, but usually do not give clinical symptoms, and do not undergo malignant transformation. They occur alone or coexist with other defects, sometimes forming a characteristic clinical picture of a syndrome of congenital defects. Mutations in genes, such as PTEN, GLI3, SDH B/D, PIK3CA and ACT1, cause a dysfunction of the tumor suppressor gene and result in an increased neoplastic transformation. Hamartoma is a lesion between developmental disorders and benign tumors, which occurs frequently in humans, but is very rare in domestic animals. In a histopathological examination, however, it is diagnosed relatively often. In the veterinary literature, both hamartoma and choristoma are attributed mostly to errors in embryogenesis and are not considered as preneoplastic lesions.

Keywords: hamartoma, choristoma, congenital malformation, tumor, PTEN

Eugen Albrecht, a German physician and pathologist (1872-1908; son of the veterinarian Michael Albrecht), at the beginning of the twentieth century, gave the name of hamartomas to nodular lesions that were a likely effect of developmental abnormalities. This term remained in medicine to date. Hamartoma is a non-neoplastic growth built of tissues typical of the organ in which it is formed, but marked by disorder in the arrangement and proportion of different types of cells. This differs from another abnormality called choristoma, which is a benign tumor composed of a normal tissue in an abnormal location, as a form of heterotopia. Hamartoma is a developmental disorder occurring in various body parts and organs. This abnormality sometimes may not cause any visible signs, remaining unrecognized, unless additional circumstances arise, such as a significant increase in its size or pressure on other organs. It occurs alone or coexists with other defects, sometimes forming a characteristic clinical picture of a syndrome of congenital defects.
Hamartoma - ,tumor arising from error” (21), a lesion between a developmental disorder and a benign tumor - is relatively frequent in humans. It is detected accidentally, for example, in the lung parenchyma. Typically spherical, sharply and clearly defined tumor with a diameter of about $2-3 \mathrm{~cm}$, located in peripheral parts of the lungs, is found during a plain radiographic examination. Histologically, it is composed mainly of adipose tissue and cartilage, arranged chaotically within the lesion (Fig. 1-4). Multiple nodules located in the walls of the bronchi are occasionally observed. Hamartoma develops mostly in men, usually in the small bronchi and less frequently $(10 \%)$ in a lumen of the large bronchi (50). It forms in two phases: first it emerges as glandular papilloma, and then tissues of mesenchymal origin, such as hyaline cartilage (sometimes elastic cartilage), adipose tissue, fibrous connective tissue and even bone and muscle tissue, proliferate in the stroma. These changes, regarded as neoplastic lesions (benign mixed tumors), grow for 


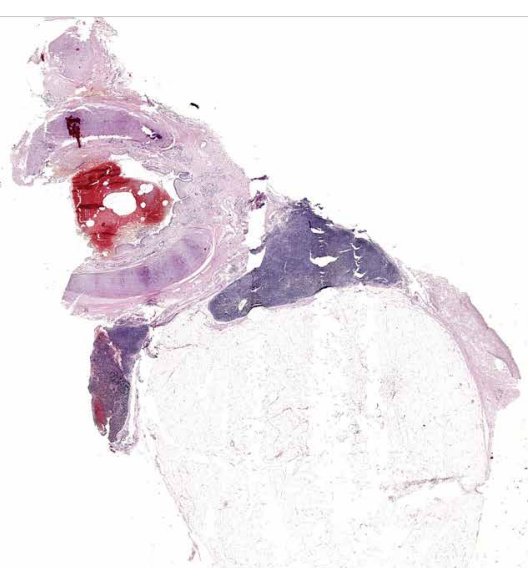

Fig. 1. Human bronchial hamartoma. Hematoxylin and eosin (HE), $\times 4$

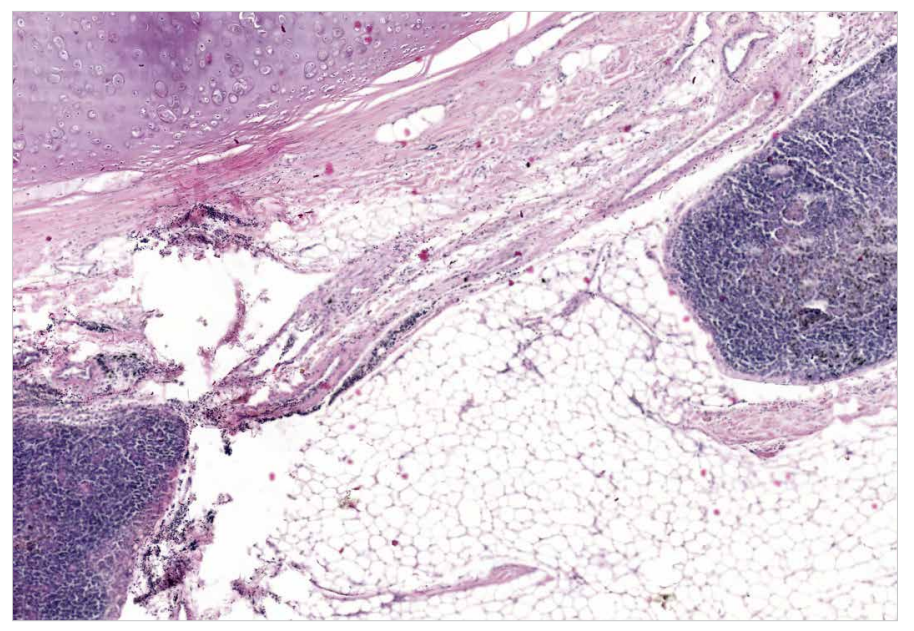

Fig. 3. Human bronchial hamartoma: adipose, connective and cartilaginous tissue as well as a lymph node with anthracosis. HE, $\times 20$

many years, usually without giving clinical symptoms, and do not undergo malignant transformation (50). In children, especially boys under two years old, fibrous hamartoma of infancy may develop, which is a rapidly growing skin or subcutaneous nodule in the region of the axillary fold, upper arm, thigh or groin (15). Typically, it is made of fibrous connective tissue, adipose tissue and myxoid stroma in which immature, round or star-shaped cells are embedded. The lesion grows fast, but is benign.

If hamartoma has the form of multiple tumors, the disease is called hamartomatosis. Its special type is Cowden syndrome, a genetic disease, whose name comes from the name of the patient first described in 1963 (39). This syndrome is a result of autosomal gene mutation inherited as a dominant trait. In most patients $(80 \%)$, the tumor suppressor gene PTEN is mutated, while in other cases KILLIN, SDH B/D, PIK3CA and AKT1 gene mutations were found (46). Tumors most frequently arise in the skin, lungs, kidneys, liver, mucous membranes (eg. in the oral cavity), thyroid gland, mammary gland or gastrointestinal tract. Due to the impaired operation of the tumor suppressor gene,

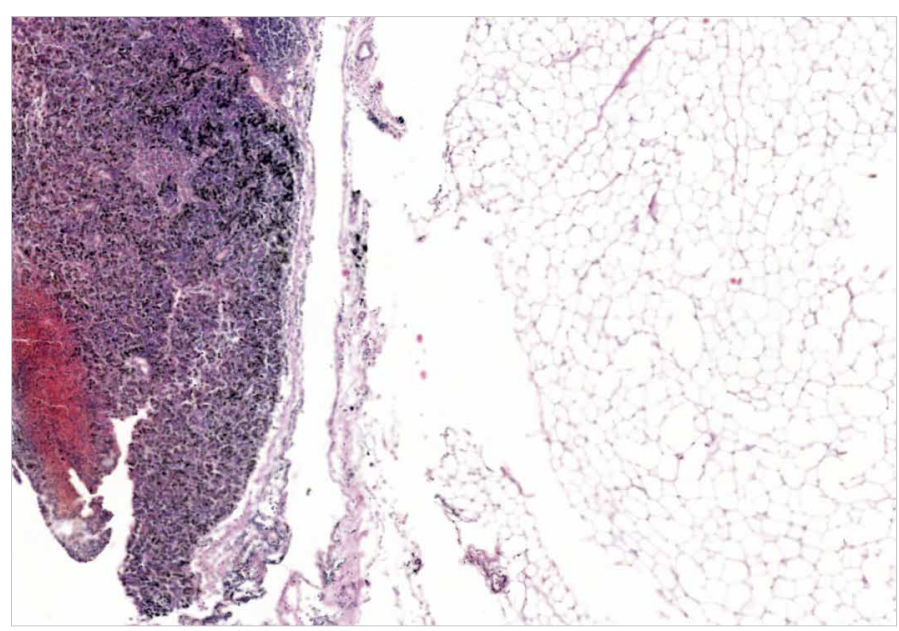

Fig. 2. Human bronchial hamartoma: adipose tissue and a lymph node with anthracosis. HE, $\times 20$

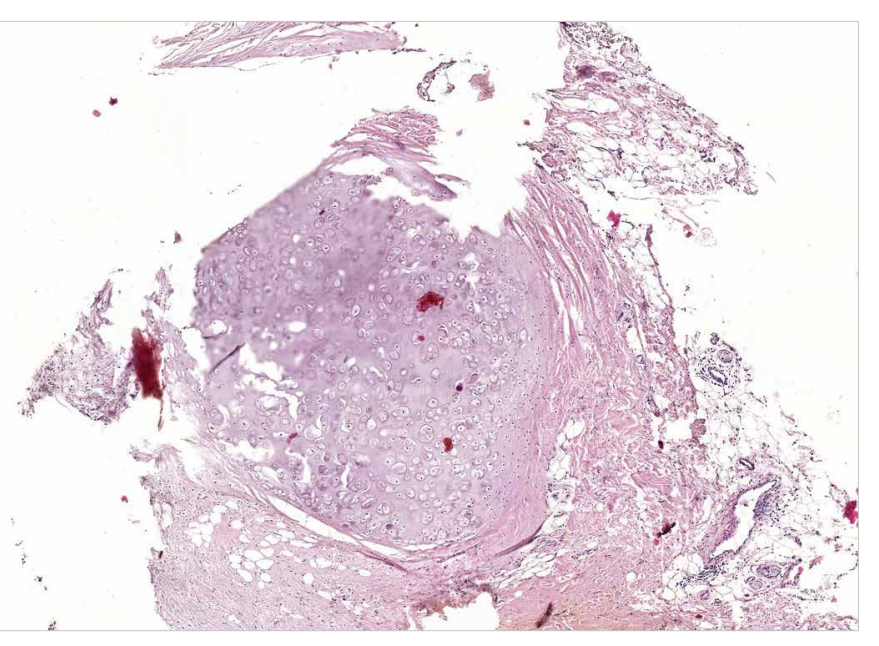

Fig. 4. Human bronchial hamartoma: cartilaginous and connective tissue. $\mathrm{HE}, \times 10$

increased neoplastic transformation occurs, mainly in the mammary gland, thyroid gland and gonads (46).

Although hamartoma per se is a non-cancerous tumor, a neoplasm called hamartoblastoma can originate from it. It develops in the prenatal life as a result of an autosomal dominant gene GLI3 deformation. The GLI3 gene belongs to the zinc finger transcription factors and is located on chromosome 18 in dogs and pigs and on chromosome 4 in cattle. GLI transcription factors (GLI1, GLI2, GLI3) play an important role in the signaling pathway that is important in the early stages of organogenesis in the central nervous system, bone, lung, prostate, limbs, muscles, hair and teeth. These factors control the proliferation of neural precursors in the dorsal structures of the brain and regulate the number of neural stem cells in embryonic, perinatal and adult brain segments (66). Mutations in this gene in humans cause Greig cephalopolysyndactyly syndrome, Pallister-Hall syndrome, preaxial polydactyly type IV and postaxial polydactyly types A1 and B.

Hamartoblastoma consists of normal, mature cells located typically, but with impaired architectural organization, since individual tissues are arranged 
randomly and disproportionately. Pathological changes can sometimes be observed in fetuses in ultrasonographic examination. A significant portion of children with a severe form of the disease, including the central nervous system, dies. Others undergo, sometimes numerous, surgeries to be able to live and function as normally as possible. There may, however, appear complications, such as epilepsy, psychiatric disorders and premature puberty. Consequences of a dominant negative mutation of the GLI3 gene in its middle region represents a special clinical form. Namely, it is an abnormal growth with features of hamartoblastoma in the hypothalamus, called Pallister-Hall Syndrome (23, 63). Hypothalamic hamartoma/hamartoblastoma may have different consequences. In some cases, there are numerous and lethal lesions, while in others they are less pronounced and non-lethal $(60,72)$.

In the veterinary literature, both hamartoma and choristoma are considered as lesions caused most probably by errors in embryogenesis. They are not regarded as preneoplastic lesions, and the tissues composing them are usually well differentiated (12). A group of non-cancerous tumors associated with mutations in the PTEN tumor suppressor gene (PTEN hamartoma tumor syndrome) is referred to as hamartoma (70). This gene is located on chromosome 26 in dogs and cattle, on chromosome 2 in cats, and on chromosome 14 in pigs. The protein encoded by the PTEN gene is involved in cell cycle regulation, and if the pathway that it mediates is functioning properly, then the final effect is a termination of cell division and the onset of apoptosis (42). Loss of the expression of PTEN was observed in tumors of many domestic animal species, e.g. in dogs with osteosarcoma (37), melanoma (31), hemangiosarcoma (14) and mammary gland tumors $(30,52,53)$. The loss of PTEN protein expression can be a useful marker in identifying mammary gland carcinoma in dogs (54).

The SDH B/D gene in dogs and cattle is located on chromosome 2 , in pigs on chromosome 6 , and in cats on chromosome 1. Succinate dehydrogenase subunit $\mathrm{D} / \mathrm{B}$ enzyme is a product of the $\mathrm{SDH} \mathrm{B} / \mathrm{D}$ gene. Mutations in this gene result in multiple endocrine neoplasia types $2 \mathrm{~A}$ and B (MEN2A and MEN2B), pheochromocytoma and paraganglioma (PGL1/PPS1, PPS/PGL, pheochromocytoma-paraganglioma syndrome) (74). The mutation 365A $>\mathrm{G}$ (Liz122Arg) in exon 4 in the SDHD gene and the mutation $113 \mathrm{G}>\mathrm{A}$ (Arg38Gln) in exon 2 in the SDHB gene were identified in 2014 (26).

The PIK3CA gene is located on chromosome 34 in dogs and on chromosome 1 in cattle. Mutations in this gene in dogs are much less frequent than in humans (9). On the other hand, the AKT1 gene in cattle and goats has been located on chromosome 21, and in dogs on chromosome 8 . This gene conditions the production of an enzyme, protein kinase B (PKB). Mutations in this gene are very rare, but if present, they are associ- ated with breast, lung, gastric, ovarian, prostatic and colonic tumors. An increased expression of several genes associated with the signaling pathway PI3K/ Akt suggests the involvement of this pathway in the pathogenesis of thyroid carcinoma in dogs (9).

The clinical picture in patients with hamartoma depends on the location and extent of hyperplasia. These pathological changes originate from different tissues. Hamartoma vascularis has been reported in animals repeatedly, and this type of tumor had different locations. For example, it was found in the skin of the tail in a 9-year-old female German Shepherd (78), in the brain of a 7-year-old Shih Tzu (59) and on gingivae in a kitten (49). A Siberian husky at the age of 6 years suffered from vascular hamartoma of the pulmonary artery and urinary bladder and was successfully treated surgically (11). In retrospective studies involving 676 scrotum tumors collected over 25 years, the vascular hamartoma was found among various other changes (71). In cats, it was also noted in the brain (44), nose (10), cervical spine (51) and cerebellum, together with hernia of the cerebellum through the foramen magnum (64).

An autopsy of an 8-year-old dog, which died of pneumonia, revealed in the right atrium of its heart a mass of tissue comprising cells of all three layers of the normal heart wall, but with impaired architecture. Congenital hamartoma of the heart muscle was diagnosed, and it was the first such case described in dogs (41).

In an approximately 10 -week-old Weimaraner, a bilateral mucopurulent nasal discharge was observed. A CT scan, performed when the animal was 6 months old, revealed proliferative changes in both nasal cavities, in the region of the ethmoid bone and in bone tissue. The dog was euthanized because of complications after biopsy, and an autopsy was performed. Samples from the proliferative lesions were subjected to histopathological examination and recognized as respiratory epithelial adenomatoid hamartoma (REAH) (36). This type of growth originates from the surface of the respiratory tract epithelium, and in humans it is considered very rare (first described in 1995). In a 56-year-old male, the mass occupied nasal cavities and paranasal sinuses (43). Even rarer is a subset of REAH called chondro-osseous respiratory epithelial adenomatoid hamartoma (COREAH), which has been reported in only 4 people. A recent report describes 3 dogs diagnosed with a nasal mass that was similar histologically to that of COREAH in people (33).

Hamartoma originating from arrector pili muscles was described in 8 dogs (38) and another was diagnosed in sudoriferous glands at the side and on the head of 2 cats. According to the authors, these changes resembled syringocystadenoma papilliferum, which occurs in humans (24). These benign tumors cause a narrowing or a complete occlusion of the external auditory canal, resulting in a progressive hearing loss 
(22). In the lungs of a cat, cartilaginous hamartoma (hamartoma chondromatosum) was found. Microcystic hamartoma with a tissue resembling alveoli, but without the presence of the bronchial tree, was diagnosed in a dog $(16,68)$. Changes defined as mesenchymal hamartoma were found on dogs' eyelids (29). Hamartoma can also occur in the gastrointestinal tract. In 2 dogs, it was present in the form of a polyp in the small intestine, where it caused partial obstruction. In one of the dogs, the lesion underwent a malignant transformation (8). Gastric smooth muscle hamartoma in an 11-year-old cat was manifested by intermittent vomiting, constipation and reduced appetite for 3 weeks. Surgical treatment was effective (62).

An interesting case of a 4-year-old bull mastiff bitch has been described. The dog was presented while being in a premature labor and treated with caesarean section, during which a round, smooth, soft, reddishbrown growth measuring $4 \times 4 \times 2 \mathrm{~cm}$ was found on one of the placenta. Microscopic examination revealed an epithelial nature of the cells, separated by fibrovascular strands of stroma. The structure resembled a labyrinth that is typical of a placenta. Because of the absence of invasive features and a low mitotic index, the lesion was considered to be benign. Eventually, placental hamartoma was diagnosed, the first such case described in a dog (13).

Just as in humans, hamartoma has been observed in animals of different ages, including very young. The onset of clinical signs depends on the severity and location of lesions. Large tumors on the skin, deformations of external body parts and neurological deficits due to lesions in the central nervous system can be seen early. For example, in a 3-month-old German Shepherd diagnosed with thalamic astrocytic hamartoma, there were signs, such as strabismus, opisthotonus, circling and thoracic limbs hypermetria (61). In a 5-month-old Great Dane bitch, a 10-cm section of colorectal polyposis was removed, and it turned out to be hamartoma. In that animal, a mutation of PTEN was found, which makes the disease similar to Cowden syndrome in humans (1). In a 4-month-old kitten, gingival hamartoma was diagnosed, and what is interesting, the lesion was accompanied by hyperglycemia, which resolved after surgical removal of the tumor along with a part of the jaw. It was recognized as a paraneoplastic syndrome hyperglycemia (49). Hyperplastic lesions of nasal conchae, referred to as mesenchymal hamartoma, have been found in young cats. They showed analogy to similar pathological nose structures found in children, who also had signs of obstruction, sneezing and epistaxis (20). A similar case of nasal vascular hamartoma was described for the first time in a cat in 2010 (10). In the 15-month-old cat, vascular hamartoma originating probably from soft tissue in the region of the first cervical vertebra was found with a secondary proliferation of bone tissue. It caused a generalized ataxia, which resolved after the lesion was removed (51).
In other cases, the disease manifests itself at an older age. Brain hamartoma in a 7-year-old dog (59), cerebral vascular hamartoma with petechiae and necrosis in an 11-year-old cat (44) and gastric hamartoma in another 11 -year-old cat (62), are just a few examples. This proves that lesions can sometimes grow very slowly and cause clinical symptoms only in geriatric animals.

There are reports of hamartoma in large farm animals as well. It has been found in the lungs of bovine (48, 57 ) and equine (27) fetuses and in the liver of equine fetuses $(7,56)$. In calves, vascular hamartoma of the right atrium (6), smooth muscle hamartoma of the abomasum (77), bile duct hamartoma (4) and vaginal hamartoma (34) have been described. Until 2016, all gingival hamarotmas described in calves were limited to the mandibular area $(65,76)$. Lately, a nasal tissuederived hamartoma in the maxillary gingiva was diagnosed in a 13-day-old calf (73). Vascular hamartomas of the liver $(5,32)$, kidney $(25)$, heart (67) and ovary $(2,35)$ have been found in adult cattle. In a 5-year-old horse, vascular hamartoma of the subcutaneous tissue of a pelvic limb was manifested with lameness (58). Similar was the case of a vascular hamartoma in a 2-year-old horse with a large soft tissue mass on a pelvic limb, which caused a slightly irregular gait of the affected limb (47). Other 2 horses euthanized for neurological deficits, such as muscle spasms, progressive ataxia and hypermetria, were diagnosed with hamartomatous myelodysplasia of the spinal cord. In one of these horses, the mass occluded the central canal of the spinal cord, forming hydromyelia (69). Also, ovarian hamartoma was described in an aborted equine fetus and a deceased 2-day-old foal $(18,55)$. Polypoid lesions having hamartoma characteristics were present in the rectum of a newborn foal (17). Vascular hamartoma has also been diagnosed in small ruminants (3, 40). Sweat gland hamartoma was reported in a newborn piglet (19). A unique hamartoma consisting of pancreatic and hepatic cells was recently found in a 7-year-old pig, which is the first case of pancreatic hamartoma reported in an animal (75). Congenital heart tumors observed in pigs and classified as rhabdomyoma may be considered as hamartoma on the basis of other criteria (45). Multiple focal hamartoblastoma was found in a pig aged 2-3 years (28).

Although this congenital defect is recognized relatively rarely, it should be taken into account during both clinical and, above all, histopathological examination in cases of proliferative lesions in animals of different ages.

\section{References}

1. Bemelmans I., Küry S., Albaric O., Hordeaux J., Bertrand L., Nguyen F., Abadie J.: Colorectal hamartomatous polyposis and ganglioneuromatosis in a dog. Vet. Pathol. 2011, 48, 1012-1015.

2. Benoit J. M., Lefebvre R. C., Mulon P. Y., Raggio I., Dore M.: Ovarian vascular hamartoma in a cow. Can. Vet. J. 2005, 46, 1026-1028.

3. Bildfell R. J., Valentine B. A., Whitney K. M.: Cutaneous vasoproliferative lesions in goats. Vet. Pathol. 2002, 39, 273-277.

4. Bosschere H. de, Ducatelle R.: Bile duct hamartoma in a calf. Vet. Rec. 1999, 144, 210-211. 
5. Braun U., Trösch L., Gerspach C., Brosinski K., Hilbe M.: Ultrasonographic findings in a cow with vascular hamartoma of the liver: case report. BMC Vet. Res. 2011, 7, 52. doi: 10.1186/1746-6148-7-52.

6. Brisville A. C., Buczinski S., Chénier S., Francoz D.: A cardiac vascular hamartoma in a calf: ultrasonographic and pathologic images. J. Vet. Cardiol. 2012, 14, 377-380.

7. Brown D. L., Anderson M., Cullen J. M.: Mesenchymal hamartoma of the liver in a late-term equine fetus. Vet. Pathol. 2007, 44, 100-102.

8. Brown P. J., Adam S. M., Wotton P. R., Gibbs C., Swan R. H.: Hamartomatous polyps in the intestine of two dogs. J. Comp. Pathol. 1994, 110, 97-102.

9. Campos M., Kool M. M. J., Daminet S., Ducatelle R., Rutteman G., Kooistra H. S., Galac S.: Upregulation of the PI3K/Akt Pathway in the Tumorigenesis of Canine Thyroid Carcinoma. J. Vet. Intern. Med. 2014, 28, 1814-1823.

10. Chambers B., Laksito M., Fliegner R., Mccowan C., Beck C., Yates G.: Nasa vascular hamartoma in a domestic shorthair cat. Aust. Vet. J. 2010, 88, 107-111.

11. Chanoit G., Mathews K. G., Keene B. W., Small M. T., Linder K.: Surgical treatment of a pulmonary artery vascular hamartoma in a dog. J. Am. Vet. Med. Assoc. 2012, 240, 858-862

12. Cullen J. M., Page R., Misdorp W.: An overview of cancer pathogenesis, diagnosis and management, [in:] Meuten D. J. (ed): Tumors in domestic animals. Iowa State Press, Ames, Iowa 2002, p. 3-44.

13. Cushing T. L., Lopate C., Schlafer D. H.: Benign placental mass with fetal growth retardation in a bull mastiff. J. Comp. Pathol. 2011, 145, 352-354.

14. Dickerson E. B., Thomas R., Fosmire S. P., Lamerato Kozicki A. R., Bianco S. R., Wojcieszyn J. W., Breen M., Helfand S. C., Modiano J. F.: Mutations of phosphatase and tensin homolog deleted from chromosome 10 in canine hemangiosarcoma. Vet. Pathol. 2005, 42, 618-632.

15. Domagała W.: Nowotwory i choroby dzieci, [in:] Stachura J., Domagała W. Patologia znaczy słowo o chorobie. Vol. 1, PAU, Wydział Lekarski, Kraków 2003, p. 155-218, 373-432.

16. Drolet R., Phaneuf J. B.: Pulmonary chondromatous hamartoma in a young cat. Vet. Rec. 1983, 113, 541-542.

17. Dunkel B., Shokek A. B., Wilkins P. A.: Congenital cystic polypoid rectal hamartoma in a newborn foal. Vet. Pathol. 2004, 41, 700-702.

18. Foley G. L., Johnson R.: A congenital interstitial cell hamartoma of the equine ovary. Vet. Pathol. 1990, 27, 364-366.

19. Gourreau J. M., Morvan H., Triller R., Marinho E., Scott D. W.: Multiple congenital epitrichial sweat gland hamartomas in a piglet. Vet. Dermatol. 2008, 19, 28-30

20. Greci V., Mortellaro C. M., Olivero D., Cocci A., Hawkins E. C.: Inflammatory polyps of the nasal turbinates of cats: an argument for designation as feline mesenchymal nasal hamartoma. J. Feline Med. Surg. 2011, 13, 213-219.

21. Groniowski J.: Patologia oskrzeli i płuc, [in:] Groniowski J., Kruś S.: Podstawy patomorfologii. PZWL, Warszawa 1991, p. 440-524.

22. Gulbinowicz-Gowkielewicz M. M., Kibiłda B., Gugała K.: Łagodne guzy przewodu słuchowego zewnętrznego wywodzące się z przydatków skóry. Otolaryngologia 2010, 9, 145-148.

23. Hall J. G.: Pallister-Hall syndrome has gone the way of modern medical genetics. Am. J. Med. Genet. C. Semin. Med. Genet. 2014, 166C, 414-418.

24. Heimann M. H., Ngendahayo P.: Sweat gland hamartoma resembling human syringocystadenoma papilliferum in two young cats. Vet. Dermatol. 2007, 18, 451-455.

25. Hodgin E. C.: Meningeal hemangioma and renal hamartoma in a heifer. Vet. Pathol. 1985, 22, 420-421.

26. Holt D. E., Henthorn P., Howell V. M., Robinson B. G., Benn D. E.: Succinate dehydrogenase subunit $\mathrm{D}$ and succinate dehydrogenase subunit B mutation analysis in canine phaeochromocytoma and paraganglioma. J. Comp. Pathol. 2014, 151, 25-34. doi:10.1016/j.jcpa.2014.03.007.

27. Hong C. B.: Congenital polyalveolar lobe in three foals. J. Comp. Pathol 1996, 115, 85-88.

28. Kadota K., Nakajima H., Nomura Y.: Splenic hamartoblastoma in a sow. J. Vet. Med. Sci. 1994, 56, 395-397.

29. Kafarnik C., Calvarese S., Dubielzig R. R.: Canine mesenchymal hamartoma of the eyelid. Vet. Ophthalmol. 2010, 13, 94-98.

30. Kanae Y., Endoh D., Yokota H., Taniyama H., Hayashi M.: Expression of the PTEN tumor suppressor gene in malignant mammary gland tumors of dogs. Am. J. Vet. Res. 2006, 67, 127-133.

31. Koenig A., Bianco S. R., Fosmire S., Wojcieszyn J., Modiano J. F.: Expression and significance of p53, rb, p21/waf-1, p16/ink-4a, and PTEN tumor suppressors in canine melanoma. Vet. Pathol. 2002, 39, 458-472.

32. Ladds P. W.: Vascular hamartomas of the liver of cattle. Vet. Pathol. 1983, 20, 764-767.

33. LaDouceur E. E. B., Michel A. O., Lindl Bylicki B. J., Cifuentes F. F., Affolter V. K., Murphy B. G.: Nasal cavity masses resembling chondro-osseous respiratory epithelial adenomatoid hamartomas in 3 dogs. Vet. Pathol. 2016, 53, $621-624$.
34. Lafond J. F., Mulon P. Y., Drolet R.: Fibrous vaginal hamartoma in a newborn calf. Can. Vet. J. 2008, 49, 61-62.

35. Lee C. G., Ladds P. W.: Vascular hamartoma of the ovary in a cow. Aust. Vet. J. 1976, 52, 236.

36. Leroith T., Binder E. M., Graham A. H., Duncan R. B. Jr.: Respiratory epithelial adenomatoid hamartoma in a dog. J. Vet. Diagn. Invest. 2009, 21, 918-920.

37. Levine R. A., Forest T., Smith C.: Tumor suppressor PTEN is mutated in canine osteosarcoma cell lines and tumors. Vet. Pathol. 2002, 39, 372-378.

38. Liu S. M., Mikaelian I.: Cutaneous smooth muscle tumors in the dog and cat. Vet. Pathol. 2003, 40, 685-692.

39. Lloyd K. M. 2nd, Dennis M.: Cowden's disease. A possible new symptom complex with multiple system involvement. Ann. Intern. Med. 1963, 58, 136-142.

40. Löhr C. V.: One hundred two tumors in 100 goats (1987-2011). Vet. Pathol. 2013, 50, 668-675

41. Machida N., Katsuda S., Yamamura H., Kashida Y., Mitsumori K.: Myocardial hamartoma of the right atrium in a dog. J. Comp. Pathol. 2002, 127, 297-300.

42. Maehama T., Dixon J. E.: The tumor suppressor, PTEN/MMAC1, dephosphorylates the lipid second messenger, phosphatidylinositol 3,4,5-trisphosphate. J. Biol. Chem. 1998, 273, 13375-13378.

43. Markowski J., Gierek T., Świderek M., Pajakk J., Witkowska M., Liszka L., Wardas $P$.: Przypadek respiratory epithelial adenomatoid hamartoma (REAH) jam nosa i zatok przynosowych. Otorynolaryngologia 2012, 11, 27-30.

44. Martin-Vaquero P., Moore S. A., Wolk K. E., Oglesbee M. J.: Cerebral vascular hamartoma in a geriatric cat. J. Feline Med. Surg. 2011, 13, 286-290.

45. Misdorp $W$.: Congenital and hereditary tumours in domestic animals. 2. pigs. A review. Vet. Q. 2003, 25, 17-30.

46. Molvi M., Sharma Y. K., Dash K.: Cowden Syndrome: Case Report, Update and Proposed Diagnostic and Surveillance Routines. Indian J. Dermatol. 2015, 60, 255-259.

47. Musterle B., Hagen R., Grest P., Kümmerle J.: Diagnostic imaging, surgical treatment and histopathological findings of a vascular hamartoma in a 2-year-old horse. Equine Vet. Educ. 2016, 28, 253-258.

48. Osborne J. C., Troutt H. F.: A congenital pulmonary anomaly (hamartoma) in a seven-month-old bovine fetus. Cornell Vet. 1977, 67, 222-228.

49. Padgett S. L., Tillson D. M., Henry C. J., Buss M. S.: Gingival vascular hamartoma with associated paraneoplastic hyperglycemia in a kitten. J. Am. Vet. Med. Assoc. 1997, 210, 914-915.

50. Papla B., Stachura J.: Choroby płuc, [in:] Stachura J., Domagała W.: Patologia znaczy słowo o chorobie. Vol. 2, PAU, Wydział Lekarski, Kraków 2003, p. 656-684.

51. Parkes J. D., Kline K. L., Riedesel E. A., Haynes J. S.: A vascular hamartoma arising from the cervical spine of a cat. J. Feline Med. Surg. 2009, 11, 724-727.

52. Qiu C., Lin D., Wang J., Wang L.: Expression and significance of PTEN in canine mammary gland tumours. Res. Vet. Sci. 2008a, 85, 383-388.

53. Qiu C. W., Lin D. G., Wang J. Q., Li C. Y., Deng G. Z.: Expression and significance of PTEN and VEGF in canine mammary gland tumours. Vet. Res. Commun. 2008b, 32, 463-472.

54. Ressel L., Millanta F., Caleri E., Innocenti V. M., Poli A.: Reduced PTEN Protein Expression and Its Prognostic Implications in Canine and Feline Mammary Tumors. Vet. Pathol. 2009, 46, 860-868.

55. Rhyan J. C., D'Andrea G. H., Smith L. S.: Congenital ovarian vascular hamartoma in a horse. Vet. Pathol. 1981, 18, 131.

56. Roperto F., Galatai P.: Mixed hamartoma of the liver in an equine foetus. Equine Vet. J. 1984, 16, 218-220.

57. Roth L., Bradley G. A.: Pulmonary hamartoma in a calf. J. Comp. Pathol. 1991, 105, 471-474.

58. Saifzadeh S., Derakhshanfar A., Shokouhi F., Hashemi M., Mazaheri R.: Vascular hamartoma as the cause of hind limb lameness in a horse. J. Vet. Med. A. Physiol. Pathol. Clin. Med. 2006, 53, 202-204.

59. Sakurai M., Morita T., Kondo H., Uemura T., Haruna A., Shimada A.: Cerebral vascular hamartoma with thrombosis in a dog. J. Vet. Med. Sci. 2011, 73, 1367-1369.

60. Saxonhouse M. A., Yachnis A. T., Burchfield D. J., Quisling R., Sullivan M. P., Pincus $D$. $W$.: Neonatal hypothalamic hamartoma: a differentiating nonlethal hamartoblastoma. J. Neurosurg. 2005, 103, 277-281.

61. Sebastianelli M., Mandara M. T., Pavone S., Canal S., Bernardini M.: Thalamic astrocytic hamartoma and associated meningoangiomatosis in a German shepherd dog. Res. Vet. Sci. 2013, 94, 644-647.

62. Smith T. J., Baltzer W. I., Ruaux C. G., Heidel J. R., Carney P.: Gastric smooth muscle hamartoma in a cat. J. Feline Med. Surg. 2010, 12, 334-337.

63. Squires L. A., Constantini S., Miller D. C., Wisoff J. H.: Hypothalamic hamartoma and the Pallister-Hall syndrome. Pediatr. Neurosurg. 1995, 22, 303-308.

64. Stalin C. E., Granger N., Jeffery N. D.: Cerebellar vascular hamartoma in a British Shorthair cat. J. Feline Med. Surg. 2008, 10, 206-211. 
65. Stanton M. E., Meunier P. C., Smith D. F.: Vascular hamartoma in the gingiva of two neonatal calves. J. Am. Vet. Med. Assoc. 1984, 184, 205-206.

66. Stecca B., Ruiz I., Altaba A.: Brain as a paradigm of organ growth: hedgehogGli signaling in neural stem cells and brain tumors. J. Neurobiol. 2005, 64, 476-490

67. Sugiyama A., Ozaki K., Takeuchi T., Narama I.: Cardiac vascular hamartoma in two slaughtered cattle. J. Comp. Pathol. 2007, 136, 202-205.

68. Takahashi K., Maeda K., Nakamura S., Fujita M., Orima H., Tagawa M. Kuwahara M., Nakashima N., Maita K.: Pulmonary microcystic hamartoma in an adult dog. Vet. Pathol. 2000, 37, 499-501.

69. Taylor K. R., MacKay R. J., Nelson E. A., Stieler A. L., Roberts J. F., Castleman $W$. L.: Spinal cord hamartomatous myelodysplasia in 2 horses with clinical neurologic deficits. Vet. Pathol. 2016, 53, 844-846.

70. Tamguney T., Stokoe D.: New insights into PTEN. J. Cell Sci. 2007, 120 4071-4079.

71. Trappler M. C., Popovitch C. A., Goldschmidt M. H., Goldschmidt K. H. Risbon R. E.: Scrotal tumors in dogs: a retrospective study of 676 cases (1986-2010). Can. Vet. J. 2014, 55, 1229-1233.

72. Tsugu H., Fukushima T., Nagashima T., Utsunomiya H., Tomonaga M. Mitsudome A.: Hypothalamic hamartoma associated with multiple congenital abnormalities. Two patients and a review of reported cases. Pediatr. Neurosurg. 1998, 29, 290-296.
73. Tsuka T., Morita T., Tanaka H., Kono S., Murahata Y., Azuma K., Osaki T., Ito N., Okamoto Y., Imagawa T.: Nasal tissue-derived hamartoma in the maxillary gingiva of a calf. BMC Vet. Res. 2016, 12, 19. doi: 10.1186/s12917-016$-0637-4$

74. Ulchaker J. C., Goldfarb D. A., Bravo E. L., NovickA. C.: Successful outcomes in pheochromocytoma surgery in the modern era. J. Urolog. 1999, 161, 764 $-767$.

75. Ushio N., Chambers J. K., Watanabe K., Kishimoto T., Li J.-Y., Nakayama H., Kazuyuki U.: Abdominal hamartoma with pancreatic and hepatic differentiation in a sow. J. Vet. Med. Sci. 2016, 78, 1373-1375.

76. Wilson R. B.: Gingival vascular hamartoma in three calves. J. Vet. Diagn. Invest. 1990, 2, 338-339.

77. Yamaguchi M., Machida N., Mitsumori K., Nishimura M., Ito Y.: Smooth muscle hamartoma of the abomasum in a calf. J. Comp. Pathol. 2004, 130, 66-69.

78. Yasuno K., Kobayashi R., Ohmuro T., Kamiie J., Sahara H., Shirota K.: Caudal vascular hamartoma accompanied by aberrant arteriovenous structures in a dog. J. Vet. Diagn. Invest. 2011, 23, 1051-1055.

Corresponding author: dr hab. Bartlomiej J. Bartyzel, PhD, Department of Morphological Sciences, Faculty of Veterinary Medicine, Warsaw University of Life Sciences, Nowoursynowska 159, 02-776 Warszawa, Poland; e-mail: bartlomiej_bartyzel@sggw.pl 